\title{
NEW TRENDS IN SHAPING TOURISM PRODUCTS IN SPATIAL UNITS ON THE EXAMPLE OF SZCZECIN
}

\author{
AGNIESZKA SAWIŃSKA \\ University of Szczecin, Faculty of Management and Economics of Services, POLAND \\ e-mail: agnieszka.sawinska@wzieu.pl
}

\author{
RECEIVED \\ 10 December 2018 \\ ACCEPTED \\ 28 December 2018 \\ JEL \\ CLASSIFICATION \\ $\mathrm{L} 83, \mathrm{R} 11, \mathrm{Z33}, \mathrm{Z38}$
}

KEYWORDS

experience marketing, marketing in tourism, city, tourism product, storytelling

ABSTRACT

The purpose of the article was to show new trends in the marketing of tourism products for cities. The article assumes that apart from typical tourist products addressed to a wide audience, new products are created in cities, based on the use of the idea of experience marketing, storytelling. These products have a unique character and are conducive to the diversification of the city's recreational offer, both for tourists and residents. The theoretical part of the article is based on a review of literature. It presents the essence of the tourist product of cities and new trends in the marketing of tourism products. In the empirical part based on the method of observation and personal interview, selected initiatives undertaken in Szczecin were presented, based on the use of the concept of experience marketing.

\section{Introduction}

Urban space is an important area for shaping tourism products. Based on endogenous potential (natural and cultural values, infrastructure and human resources), various types of tourism products have been and still are being created, and, when combined, create a comprehensive tourism product of cities. Increasing competition that concerns both travel companies and spatial units, as well as difficulties in creating a tourism product unique for the 
city, make it necessary to observe changes in tourism consumption, as well as among other entities operating on the tourism market. Not only the behaviour of consumers on the market, but also the needs and expectations of tourists are changing. This necessitates changes in marketing activities undertaken by travel companies, organizations or local government units.

The article assumes that apart from the flagship tourism products of cities, which are addressed to a great number of recipients, there can be distinguished new products created in cities, which are not only a response to today's tourists' needs and new trends in marketing, but also an alternative to traditional products. These products are often created on the initiative of residents and enthusiasts, and are then changed into commercial products. More and more often, these products are perceived by city authorities as brand products that can constitute an important element of tourism promotion of the city, as well as an element of shaping the identity of residents. Although intended for tourists, they are also attractive for residents.

The article aims at indicating new trends in shaping tourism products of the area. Therefore, it is divided into three parts. The first part refers to theoretical issues related to the tourism product of cities, whereas the second part indicates new trends in the marketing of tourism products. The third part presents selected initiatives undertaken in Szczecin, based on the use of the concept of experience marketing.

\section{Urban space and tourism product - theoretical considerations}

The literature on the subject more and more often discusses the issues concerning the tourism product with regard to local government units. This is mainly due to the growing importance of the use of endogenous potential (especially values) in shaping urban space that is friendly and useful for both residents and tourists.

As indicated by S. Liszewski (2014, p. 38), the determinant of urban space is its organization, non-agricultural economic function, legal status and "urban community", i.e. organizational, functional and social characteristics. The urban space includes, among others, free time space, i.e. one in which all activities related to the development of free time take place, and excludes the so-called "home" space understood as a place of permanent residence (a specific address) (Włodarczyk, 2011, p. 15). These can be activities undertaken either by tourists or residents. Moreover, free time space may comprise occasional activities (e.g. visiting the museum, walking along the tourist trail) or routine behaviours (e.g. going to the cinema, restaurant, swimming pool). This area is divided into recreational and tourism spaces, with this division being justified, among others, by marketing reasons. This may also be related to activities carried out within the territorial marketing of cities, in situations when it becomes important to identify and meet the needs of many groups of stakeholders (residents, tourists, entrepreneurs, students or investors). In the case of recreational and tourism space, these needs are often similar or identical, and their satisfaction brings benefits to many recipients.

As indicated by B. Włodarczyk, important elements of the tourism space of the city are the natural and cultural heritage, infrastructure, and the man who not only uses this space, but also organizes and manages it (Włodarczyk, 2011, p. 17). Elements of the tourism space are the basis for creating the tourism product of the city, which is in line with the definition of a tourism product proposed by D. Buhalis. This author interprets the tourist reception area as a tourism product, which consists of individual tourist services and public goods such as natural and anthropogenic values as well as the socio-cultural environment of the area (Orfin-Tomaszewska, 2016, pp. 65-66).

Tourism product of an area is characterized by a set of features that are characteristics only for it. One of them is the spatial feature, which is the resultant of the geographical environment and heritage (historical and cultural) 
of a given area, and which is closely related to the use of the product in a specific place. In addition to the spatial character of the tourism product of an area, its characteristic features are complexity and multiproduction. Mutual complementation of product elements proves its complementarity and the possibility of achieving synergy, thanks to the integration of activities of many entities creating the tourism product of an area (Orfin-Tomaszewska, 2016, p. 66). Such a product is comprehensive and covers the tourism offer of the area created by economic entities (travel companies) operating on the tourism market, but also by or with the participation of local government units or tourism organizations. It is a product understood on a macro scale, which includes goods, services and other offers delivered to service recipients (Mazurkiewicz, 2005, p. 83).

M. Marczak and J. Bożyszkowski (2009) present a different approach to the definition of an area as a tourism product, by stressing that the product of a tourist reception area should not be equated with tourism supply in a given area. In order to define the tourism product, elements of tourism supply should be subject to a common concept aimed at satisfying the needs of tourists. This means that the same area can offer several products addressed to various groups of recipients, and that one of the most important management problems is the proper selection of their assortment (Dziedzic, 1998, p. 23).

On the other hand, A. Panasiuk, points out that the tourism product of an area can be interpreted in two methodological approaches:

a) subjective - developed by tourist destinations with existing (material as well as non-material) elements of tourism potential of an area and then presented on the market as an offer of that area;

b) psychological - resulting from tourists' ideas and expectations concerning a tourist destination and supported by the selection of material and non-material elements enabling creating an individual offer for a specific tourist (Panasiuk, 2014, pp. 112-113).

Although the author indicates that the image does not constitute an element of the offer, it is undoubtedly an image of the perception of the product's identity. From the marketing point of view, both approaches should be considered important when creating a competitive tourism product of an area.

As underlined by K. Orfin-Tomaszewska (2016, p. 63; Żemła 2003, p. 22), the concept of a tourism product of an area results from the development of territorial marketing, which is nowadays an indispensable element of the activities of local government units. A. Niedzielska emphasizes that recent years have proven that marketing activities carried out by local authorities are necessary and support the implementation of important development goals of local governments (Niedzielska, 2017, p. 144). These include, among others, an increase in the competitiveness of a specific urban space. Furthermore, as previously indicated, urban space may comprise different types of tourism products, of both simple (such as accommodation services, pilotage or guiding) and a more complex nature (trail, event). Moreover, these can be both products offered by entrepreneurs, i.e. of a commercial nature; but also products initiated by associations or products of public and often non-profit nature offered by the city. Such products may also include unique goods that are characteristic for a given city, as well as products that are popular in their own way, and thus reproducible. The variety and richness of these products means that achieving success in the market requires following new marketing trends, regardless of the kind/type of product.

\section{Selected trends in tourism marketing}

The literature studies conducted for the purposes of the article indicate the growing interest of researchers in the subject of experience marketing. 
When presenting the essence of experience marketing, it should be noted that this concept is relatively new to Polish literature and is most often understood as distinguishing the offer by creating experiences that accompany consumption. Among the main factors influencing its distinguishment, the most often mentioned factor is postmodernism, where consumption plays the most important role, with products, apart from their use values, becoming carriers of attitudes, lifestyles or beliefs. Furthermore, the ritualization of the consumption process is indicated as a premise, which shows that the modern consumer expects sensation, emotions and extreme experiences, and that the progressive diversification of the offer addressed to consumers makes products more adaptable to their expectations and needs. Moreover, the uniformity of product standards limits the possibilities of creating a competitive advantage in a given area, as well as is a factor indicating the need to look for new solutions for marketing product development based on experience (Brandys, 2016, p. 13).

The need to take the concept of experience marketing into consideration is also noticed in the creation and management of tourism products, especially tourist attractions. This subject has been investigated by, among others, A. Stasiak, B. Marciszewska, M. Żemła, A. Niezgoda, S. Bosiacki. Tourism is a field whose basic "product" is, by definition, experience. Thus, cultural institutions or travel companies transform into specific factories of emotions, sensations, thrills and memories (Żemła, 2017, p. 10).

For example, A. Stasiak (2015, p. 335) emphasizes that nowadays the consumption of goods becomes of secondary importance, while the importance of sensations and emotions increases. Moreover, A. Stasiak attempts to determine experience as a market offer (p. 335). He points out that experience is not a new phenomenon, as it has always existed as an involuntary, accidental, not fully realized and unplanned result of the customer's contact with the company (service provider). Interactions between these entities leave specific, highly individualized traces in the client's psyche. The trick is to give them the right shape and emotional appeal that is desired by buyers, as well as make them memorable. This is possible only in the case of events that engage an individual at the emotional, physical, intellectual and spiritual levels (Stasiak, 2015, pp. 335-336).

On the other hand, A. Niezgoda emphasizes the importance of the experience economy theory assumptions for travel companies. In order to become part of this new market, they must abandon the current thinking and behaviour pattern when designing and creating the tourism product. Instead of focusing on the functionality of the product, excessively taking care of the highest possible quality of services, etc., they should, first, assess the way consumers consume the product, including, in particular, the analysis of the experiences and satisfaction that may arouse in their minds. Consumers of the experience market want to spend their time as effectively as possible, primarily on products that provide a wealth of unforgettable experiences. During a trip, they want to experience as much as possible (Stasiak, 2015, p. 336; Niezgoda, 2013).

When referring to B. Pine and J. Gilmore (1999), A. Stasiak presents selected recommendations for the development of tourism products based on marketing experience, which include:

a) organization of experiences around a specific topic - to facilitate the creation of a coherent, expressive, easily memorable image, and to distinguish oneself from the competition;

b) striving to create positive impressions during every contact with the client;

c) striving to eliminate negative impressions (including those that are contrary to the leading topic or just distract customers from it);

d) creating multi-sensory products that affect all the tourist's senses - the more involved senses, the stronger emotions and experiences, and consequently, a better-remembered experience, more vivid memories, etc.; 
e) preparing memorabilia related to the experience, which will enable longer preservation of undergone emotions, reliving moments from the past, the opportunity to recall memories and share them with others.

Application of experience marketing results in the so-called the "wow!" effect, which is a concept that is gaining more and more popularity in marketing practice. The term comes from English, where the word "wow" has several meanings: 1. hit, 2. great (sensational) success, 3. great (terrific) thing, 4. make a great impression, excite. However, it is used most often as an enthusiastic exclamation simultaneously expressing admiration, surprise and respect. Involuntarily uttered "wow" is the greatest compliment, a sign of the highest recognition and acceptance. In marketing, the "wow!" effect is understood as the state of the highest customer satisfaction, resulting from the extraordinary gratification with the purchase made and the benefits gained; surprise by an exceptional, above-average experience. When preparing an offer, it is worth knowingly planning the elements that will delight customers. The selected components of the tourism sector's offer, which may contribute to the unique and memorable experience of their clients, include both small, seemingly insignificant gestures and behaviours, as well as significant, additional goods and services (e.g. interpretation of heritage by a pilot or guide (storytelling), playing music, dressing up costumes, urban games (Questing), staging, personal contact with a service provider, interior design, surprises and gifts (Stasiak, 2015, pp. 342-344).

An example of the application of "experiences" in the city's marketing activities is Kraków. The City Council of Kraków in 2016 approved the Strategic Program of Promotion of the City of Kraków for 2016-2022 (Program Strategiczny Promocji Miasta Krakowa na lata 2016-2022), whose main promotional idea was expressed in the "Kraków gives meanings and moves minds" slogan. It was based on the so-called Emotional Selling Proposal (ESP) - an innovative concept in line with current trends in territorial marketing, which emphasize the evocation of specific emotions and the use of associations related to a given place. According to the assumptions of ESP, the modern consumer is less interested in the rational aspect, tourist attractions or heritage, and more in the sensations and emotions. For example, according to the new approach, the concept of communication related to the organization of a sporting event implies evoking specific emotions among the recipients, for example, emphasizing the importance of relationships, the spirit of fair play and free time, whereas activities related to festivals and cultural events supported by the city should be selected to show authenticity, the creators' freedom and imagination (Kamińska, 2017, pp. 10-11) Thus, the Strategic Program of Promotion of the City of Kraków includes a task dedicated to tourists named "Kraków Moves New Places". The task brings together undertakings aimed at promoting new places, districts and products among tourists, in order to enrich and diversify the tourist offer of Kraków and intensify tourism outside the city centre itself (Program strategiczny..., 2016).

Another trend in marketing that can be used in promotion, arrangement and provision of tourism products is the so-called storytelling, also known as narrative marketing. It involves building the company's image (its products and services) by creating a story about it. Under the concept of the story lies the authentic plot that is devoid of marketing jargon, reveals the history of the brand or product, refers to the emotions of the recipient, as well as stimulates their imagination (Orlikowska, 2017, p. 18). Although the idea of "storytelling" is nothing new for guides, it should be recognized that the ability to use it influences the assessment and reception of tourist attractions. Story is the art of choosing words and metaphors to illustrate a certain idea or wisdom in a way that stimulates the imagination and arouses emotions. Passing on history and legends is a way of communication that has existed for centuries, becoming the foundation of cultural heritage. In the new dimension, it is a tool for learning, remembering, combining facts and understanding the context as a whole. Oral tradition help listeners 
understand the motives of their characters' actions; it can inspire, motivate, activate, and stimulate creativity thanks to the emotional load contained in it. Storytelling encourages local narrators to pursue their own activities and search for ways to build interesting stories based on local tradition (Połucha, 2015, pp. 63-74). The example of the introduction of experience marketing to the tourism industry is the evolution of museums - from a place where heritage is collected and presented into a place providing specific experiences and active participation of visitors. Moreover, the role of the guide in cognitive tourism has undergone some changes. The modern tourist guide has to not only communicate the facts, but also interpret the encountered heritage. This comes down to explaining different meanings and dependencies by choosing original sites, directly experiencing them, using various media, as well as being emotionally involved (Kruczek, Kurek, Nowacki, 2010). The interpreter's job is to help tourists understand the meaning of a given place, its unique history and present time, as well as fully experience the visited area with all senses (Stasiak, 2013, p. 32), while providing tourists with unforgettable impressions, emotions and entertainment (Żemła, 2017, p. 12).

It should be noted that new forms of sightseeing are complementary to traditional tourist services, with the goals of using experience being:

- promoting and highlighting natural and historical-cultural heritage, showing values that are not noticed during traditional sightseeing,

- encouraging tourists to explore the surroundings by themselves,

- interactive sharing of information regarding visited places,

- learning about sites that are outside the marked trails,

- educating through active participation in organized events,

- enabling tourists to co-create a tourism product,

- involving a wide range of participants as a result of gamification (Połucha, 2015, p. 69).

\section{Selected tourism products of "experiences" of Szczecin}

For the purpose of this article, selected tourism products of the city were presented, whose concept of creation is based on the experience marketing, and which are at the initial stage of introduction to the tourism market of the city. The selection of products was purposeful. These are the "The PRL Trail" and "The Underground Trails of Szczecin". The first product is a new venture that was created on the citizen's initiative, while the other has an established position on the Szczecin market and constitutes an offer of a travel company. Moreover, both products are unique and can be an alternative to traditional tourism products of the city.

"Szczecin on the PRL trail" is described by its author (Justyna Machnik guide) as a trail leading around Śródmieście (Midtown) (mainly Wojska Polskiego Avenue and Jagiellońska Street), whose aim is to present the Szczecin symbols of a bygone era - flavours, fashion, music, culture, industry. The trail is located a little bit further from the typical monuments and architecture that represent the socialist-realist style, as well as places where Paprykarz Szczeciński (Szczecin goulash) was being sold, big-beat was listened to, and people queued for clothes. Here, the dullness of the Polish People's Republic (PRL) mingled with entertainment and cultural animation. A particular attention is paid to mosaics and neon signs. The participants of the trail are guaranteed tastings, riddles and retro-prizes. 
It is worth noting that the initiative required cooperation with many entities. It was noticed by the City of Szczecin, precisely by Żegluga Szczecińska Turystyka Wydarzenia Sp. z 0.0., ${ }^{1}$ which included the trail in the Szczecin City Walk offer (Szczecińskie Spacery Miejskie). The product was also noticed by the Marshal's Office of Zachodniopomorskie Voivodeship and was part of the Zachodniopomorskie Heritage Days 2018 program (Zachodniopomorskie Dni Dziedzictwa 2018). Moreover, the creator of the product cooperated with entrepreneurs that included, among others, Mark Invest - Kosmos cinema, Minifot photography studio, Pasztecik, Pizzeria Piccolo, ProMedia store, Bistro Rybne Seamor, Bistro Gruba Ryba by Seamor, Primo store, Stella hair salon, Ziemniak i Spółka and Szczecińska Agencja Artystyczna. However, it should be noted that the activities of these companies are associated with the traditional products of the city, which constitute the Szczecin brand (e.g. Pasztecik). The inhabitants of Szczecin and sales staff from the kiosk located on the trail - Mr. Marika and Renata - were also involved in the initiative, a fact that indicates individual character of the undertaking.

As it has already been mentioned, the product is in the phase of introduction into the Szczecin market, as the premiere of the trail took place in June 2018. Despite the short product life, its fan page on the social networking site Facebook is observed by 508 (as of 19.11.2018).

The interactive, innovative character of the product and interest in the trail are also reflected in press reports. The article of "Kurier Szczeciński" present a review of the trail, which focused on the beginning of the event with the sounds of big-beat; the opportunity to get to know the city from a typical tourist side; refreshments in the form of sweets and Szczecin goulash; visit to the iconic Pasztecik; opportunity to smoke "Popularne" cigarettes"; as well as presenting each gentlemen with a tie, because, as everybody knows, men in ties "make less fuss". The atmosphere of the previous era was also depicted by Justyna Machnik, a guide. Her handbag and suitcase were hiding many surprises, among others, entry tickets to the currently closed "Kosmos" cinema. The more diligent participants received prizes. For the correct answer to a difficult question, you could win a few rolls of grey toilet paper on a string or a small amount of money. "It turns out that everything is possible in Szczecin - you can even fill your pockets during a free walk!" (Spacer krzepi, 2018). The initiative was also mentioned in Głos Szczeciński, as well as in broadcasts of Radio Szczecin.

The other product, which refers to the heritage of the city, and whose today's concept is also based on experience, is the offer of Centrum Turystyki Magnolia company, named "The Underground Trails of Szczecin". This is not a new product, as it was included in Szczecin's offer in 2008. In 2009, the product received the POT (Polish Tourist Organization) certificate for the best tourism product in Zachodniopomorskie Voivodeship. The basic offer of "The Underground Trails of Szczecin" includes two routes that have been prepared for tourists in the largest civil shelter in Poland that is open to public $\left(2.5\right.$ thousand $\left.\mathrm{m}^{2}\right)$. Its entire space was arranged in such a way so that it would reflect the life in a shelter, with numerous furniture, everyday objects, etc. placed all over it. In the shelter, visitors can follow one of two specially prepared trails. The "World War II" trail reconstructs the life in a shelter during air raids and presents the technique of building a shelter. The other - "Cold War" - presents the history of the shelter and everyday life during the Cold War period. It takes about an hour to visit each trail.

\footnotetext{
${ }^{1}$ Żegluga Szczecińska Turystyka Wydarzenia Sp. z o.0. is a company whose activities stipulate a public service obligation. The primary purpose of its operation is to perform tasks of the City of Szczecin. The company's tasks include administering wharfs owned by both the City of Szczecin and the company, as well as, among others, the provision of tourist-recreational and cultural services and port services for tourist and passenger units. The company also organizes events, fairs and promotional exhibitions.
} 
The shelter is also an original venue for the organization of various events, such as concerts, theatre performances, as well as interesting integration events (www.polska.travel).

Observation of the functioning of the entity in the recent years allows noticing the continuous development of the offer. In addition to visiting the basic trails, the last year brought about an offer for small groups called "Sightseeing with a thrill", during which participants illuminate the route with flashlights. The company also offers the opportunity to use the so-called museum lessons. This year's offer is named "For the Glory of the Homeland 1918-2018". The aim of the lesson is to consolidate information related to the 100th anniversary of regaining independence by Poland through play and participation in the reconstruction of the appointment of Józef Piłsudski as the Riflemen Legion Commander. The exhibition is run by the author, whose family history is related the Polish Legions, and who, during the "lesson", is dressed up in the uniform of the captain of the 1st Brigade, Józef Piłsudski. During the visit, the participants are divided into groups and take part in a contest (an element of competition). Moreover, all participants are appointed riflemen, receive a nomination diploma, and at the end of the lesson, sing the songs of the 1st Brigade together. It should be added that the short version of the lesson is also a part of the basic version of the offer organized every Sunday at 12 (www.schron.szczecin.pl).

The offer of "Underground Trails" is very popular among both tourists and the residents of Szczecin. It is possible to participate in such events every day throughout the year. The product also has its own website, as well as promotes itself using the social networking site Facebook. The number of likes of the website is 4,296, which is a sign of interest in the product. In addition, information about it can be found on szczecin.eu, visit.szczecin, trip. advisor.

\section{Conclusions}

The considerations presented in the theoretical part indicate the main trends observed in tourism marketing. Marketing shaping a tourism product based on the use of the concept of experience, storytelling or creating an experimental sale proposal, is becoming an indispensable element of the marketing activity of all entities creating the tourism product of cities.

Szczecin is a city whose tourism product is diverse. This creates difficulties in defining the unique proposal to sell a comprehensive tourism product of the city. Nevertheless, the tourism policy entities of the city understand the necessity to follow modern marketing trends (Żegluga Szczecińska Turystyka Wydarzenia Sp. z 0.0., the Marshal's Office of Zachodniopomorskie Voivodeship, West Pomerania Regional Tourism Organization). In their activities, these entities support the initiatives of already existing and new tourism experience products - a fact which contributes to the promotion and development of the tourism product of the city, enhances the free time space for both tourists and residents, as well as builds the city's identity and, consequently, its desired image.

Despite not being the only tourism products in the city, the presented examples of tourism products of "experiences" of Szczecin, based on the concept of experience and storytelling, are evidence of the high awareness and sense of current trends, while creating a unique offer. Moreover, the success of the "Underground Trails of Szczecin" product, and its observed development, prove that this is the right direction of the marketing development of tourism product of an area. 


\section{References}

Brandys, I. (2016). Marketing doświadczeń - założenia i perspektywy. Zeszyt Naukowy Wyższej Szkoły Zarządzania i Bankowości w Krakowie, 42, 13-23.

Dziedzic, E. (1998). Obszar recepcji turystycznej jako przedmiot zarządzania strategicznego. Monografie i Opracowania No. 442. Warszawa: Szkoła Główna Handlowa.

Kamińska, N. (2017). Kraków w zgodzie z trendami-stawia na emocje. Wiadomości Turystyczne, 13, 10-11.

Kruczek, Z., Kurek, A, Nowacki, M.(2010). Krajoznawstwo. Teoria i metodyka. Kraków: Proksenia.

Liszewski, S. (2014). Miejska przestrzeń turystyczna. Metody Badań. Ewolucja i jej prawidłowości. Turyzm, 24 (1), 37-47.

Marciszewska, B. (2010). Produkt turystyczny a ekonomia doświadczeń. Warszawa: C.H. Beck.

Marczak, M., Bożyszkowski, J. (2009). Region (obszar) jako produkt turystyczny. Zeszyty Naukowe Wydziału Nauk Ekonomicznych Politechniki Koszalińskiej, 13, 117-125.

Mazurkiewicz, L. (2005). Produkt turystyczny w ujęciu marketingu terytorialnego. In: K. Pieńkoś (ed.), Konkurencyjność produktu turystycznego (p. 83). Warszawa: Wyższa Szkoła Ekonomiczna.

Niedzielska, A. (2017). Terytorialny marketing doświadczeń na przykładzie miasta Częstochowa. Marketing i Zarządzanie, 1 (47), 143-152.

Niezgoda, A. (2013). Rola doświadczenia w zachowaniach konsumenta na rynku turystycznym. Koncepcja ekonomii doświadczeń i marketingu doznań. Folia Turistica, 28, 91-106.

Orfin-Tomaszewska, K. (2016). Polityka promocji w kreowaniu wizerunku produktu turystycznego, Szczecin: Wydawnictwo Naukowe Uniwersytetu Szczecińskiego.

Orlikowska, M. (2017). W marketingu liczy się opowieść. Wiadomości Turystyczne, 22, 18.

Panasiuk, A. (2014). Rynek turystyczny. Studium strukturalne. Warszawa: Difin.

Pine, B.J., Gilmore, J.H. (1999). The Experience Economy: Work Is Theater and Every Business a Stage. Harvard Business School Press.

Połucha, I. (2015). Turystyka jako gra - innowacje w aktywizacji turystycznej. Ekonomiczne Problemy Turystyki, 1 (29), 58-71.

Program strategiczny promocji miasta Krakowa na lata 2016-2022 (2016). Retrieved from: https://www.bip.krakow.pl/_inc/rada/ posiedzenia/show_pdfdoc.php?id=86717.

Spacer krzepi (2018). Kurier Szczeciński. Retrieved from: https://24kurier.pl/aktualnosci/wiadomosci/spacer-krzepi.

Stasiak, A. (2013). Produkt turystyczny w gospodarce doświadczeń. Turyzm, 23 (1), 29-38.

Stasiak, A. (2015). Triada Doświadczeń Turystycznych i efekt „WOW!” podstawą kreowania nowoczesnej oferty turystycznej. Prace Naukowe Uniwersytetu Ekonomicznego we Wrocławiu, 379, 332-347.

Włodarczyk, B. (2011). Przestrzeń turystyczna - kilka słów o istocie pojęcia. In: M. Durydiwka, K. Duda-Gromada (eds.), Przestrzeń turystyczna. Czynniki, różnorodność, zmiany (pp. 15-28). Warszawa: Uniwersytet Warszawski, WEMA Wydawnictwo-Poligrafia Sp. z 0.0 .

Żemła, M. (2003). Podstawy funkcjonowania strategii kształtowania produktu turystycznego regionu. Katowice: Górnośląska Wyższa Szkoła Handlowa im. Wojciecha Korfantego.

Żemła, M. (2017). Rola koncepcji ekonomii doświadczeń w postmodernistycznej interpretacji, trendów rynkowych w turystyce i budowie nowoczesnych produktów turystycznych. Prace Komisji Geografii Przemysłu Polskiego Towarzystwa Geograficznego, 31 (3), $7-16$.

Cite this article as: Sawińska, A. (2018). New trends in shaping tourism products in spatial units - on the example of Szczecin. European Journal of Service Management, 4 (28/2), 403-411. DOI: 10.18276/ejsm.2018.28/2-48. 